\title{
The Rule of Law and National Security in Nigerian Democracy: A Contemporary Issue under the Aegis of International Law
}

\author{
By Isaac O. C. Igwe*
}

\begin{abstract}
Although brutality can repress a society, it never assures the sustainability of that conquest. Tyranny steers the hopeless to despair, edges to rebellion, and could open the door for a new tyrant to rise. Law becomes a limiting factor that must act as a stopgap to the avaricious intentions of a dictator. A democratic leader must incorporate the supremacy of the law and honest officials into his government. He shall also create courts of law, treat the poorest citizens with fairness and build a hall of justice to bring the society to modernity with the operation of the rule of law enshrined in the constitution. Legislation is nothing without enforcement and Law is no law if not accepted and respected by the people. The rule of law cannot be said to be working in a country where the government continues to violate the orders of the court, unlawfully detain its citizens, abuse human rights including arbitrary and extra-judicial executions, unlawful arrests and detentions, embargo on freedom of speech and press, impunity and inhumane torture, degradation of people or exterminations. This treatise will argue on the supremacy of the "Rule of Law" as it impacts Nigerian democracy.
\end{abstract}

Keywords: Rule of Law; Democracy; Judiciary; Supremacy; Government; Tyranny; Nigerian Constitution.

\section{Introduction}

The rule of law got to its crescendo in the $19^{\text {th }}$ century through the British jurist A.V. Decey. Although the credit to modern 'Rule of Law' is given to A. V. Decey $^{1}$ the development of the concept can be linked through the civilisation history of ancient Greece; Mesopotamia, Rome, China and India. ${ }^{2}$ Nonetheless, the phrase was acknowledged by prehistoric sages and philosophers like Aristotle who wrote "it is more proper that law should govern than any one of the citizens." 3 Law is collection of rules created and enforceable through the government institutions or social entities to regulate behaviour. It is a system that monitors and makes sure citizens and governments conform to due process. Enforceable laws are made by legislatures or by legislator, resulting in statutes, by executives by way of decree or regulations or through judicial precedents established by Judges, usually in jurisdictions under common law. Individuals can

\footnotetext{
"LLB (Hons), Barrister \& Solicitor Supreme Court of Nigeria, LLM, Ph.D. (Law), Birkbeck, University of London, London, UK. Email: isaacigwe@ hotmail.com.

${ }^{1}$ See Wormuth (2010).

${ }^{2}$ See Black (2009).

${ }^{3}$ See Aristotle at 16.
} 
create laws in the form of legally binding contracts and arbitration agreements which are normally enforceable through a regular court process. Laws are formulated in line with the constitution, written or unwritten and address complex issues concerning equality, fairness and justice. The law moulds society, history, economics, and politics in diverse ways and operates as a mediator of relations between individuals. Rule of law connotes that everyone is subject to the law. ${ }^{4}$ According to John Marshall,

"the framers of the Constitution contemplated that instrument as a rule for the government of courts, as well as of the legislature. ",

Opposed to the rule of law is autocracy, dictatorship or oligarchy, a system that holds the leader above the law. Plato advocated for respect to the law and opined that without the law in the society the collapse of the state is imminent, but the presence of law in a state makes the government subservient to the law and enables the citizens to fully benefit the advantages of that state. ${ }^{6}$ Plato believed that a leader should be loved by his citizens and the leader's personal interest should not be above the interest of his citizens. Whilst Niccolo Machiavelli took the opposite view and arrived at a different conclusion that leaders should be better feared and respected by his citizens than loved, ${ }^{7}$ otherwise, his people might think he is weak and take advantage of him. His conclusion was informed by his believe that men are naturally wicked and in order to be in control, the leader needs to be feared. ${ }^{8}$ Marcus Aurelius believed that the law is supreme and above everybody. Although Aurelius agreed with both Plato and Machiavelli in so far as the leader is doing the right thing within the law. He stated that it does not matter what others think about the leader as long as the leader is acting in accordance with the law. Aristotle however, vehemently was opposed to giving ultimate power to a leader above the law rather he opined that such leader's power should be beneath the law. In order words, Aristotle was an advocate of the rule of law and he said:

"that it is more proper that law should govern than any one of the citizens: upon the same principle, if it is advantageous to place the supreme power in some particular persons, they should be appointed to be only guardians and servants of the laws."

In the Roman Empire period, the sovereign was not personally subject to the laws, nevertheless, where there is grievance, those affected can sue the treasury. ${ }^{10}$ It is often roughly stated after Cicero - a Roman statesman that "we are all servants of the laws in order to be free." 11 The School of legalism in Ancient

\footnotetext{
${ }^{4}$ See Hobson (1996) at 57.

${ }^{5}$ Ibid, at 57.

${ }^{6}$ See Cooper \& Hutchins (1997).

${ }^{7}$ See Dalter (2016).

${ }^{8}$ See Machiavelli (1882).

${ }^{9}$ See Aristotle (1988) at 16

${ }^{10}$ See Bingham (1949) at 28

${ }^{11}$ See Cicero: "The Magistrates who administer the law, the Judges who act as its spokesman, all the rest of us who live as its servants, grant it our allegiance as a guarantee of our freedom."
} 
China argued that law should be used as a tool of governance, and thus implemented "rule by law" and not "rule of law", which by implication kept the aristocrats and emperor immune before the law. ${ }^{12}$ In the middle ages Islamic jurisprudence, the law was formulated to be above everyone including the $\mathrm{Caliph}^{13}$ It does not relate to secular law, but refers to Sharia law. ${ }^{14}$ In the $9^{\text {th }}$ Century, Alfred the Great, Anglo Saxon King of England held in his reformed kingdom code of law (the Doom Book) that the application of law should be equal to all persons, whether rich or poor, friends or foes. The law of his kingdom was motivated by Leviticus, 19:15:

"You shall do no iniquity in judgement. You shall not favour the wretched and you shall not defer to the rich. In righteousness you are to judge your fellow."

In the early modern age, Samuel Rutherford in Lex Rex (1644) stated that the King is under the rule of law. ${ }^{16}$ However, it is difficult to juxtapose the kings from the law where in Latin lex, rex means [the law is king], which in traditional Latinic maxim rex lex means [the king is Law]. ${ }^{17}$

Britain, France and USA played a pivotal role in spreading the principles of the rule of law across the countries of the world. ${ }^{18}$ The notion that no one is above the law was popularised in 1776 during the founding of the United States and this influenced Thomas Paine's pamphlet "Common Sense" and he stated that:

"in America, the law is King. For as in absolute governments the King is law, so in free countries, the law ought to be king, and there ought to be no other.",19

This was followed suit by John Adams "a government of laws and not of men," expressed in the Massachusetts constitution:

"In the government of this commonwealth, the legislative department shall never exercise the executive and judicial powers, or either of them; the executive shall never exercise the legislative and judicial powers, or either of them; the judicial shall never exercise the legislative and executive powers, or either of them; to the end it may be a government of laws, and not of men. $" 20$

This paper will examine the concept "Rule of Law" in general terms, as a model of governance and articulate its applicability in a democratised society with particular emphasis to Nigeria. The paper will critically explore the theoretical and philosophical basis of rule of law as it impacts on democracy and use it to analyse the Nigerian government. Finally, the paper will attempt to argue the supremacy of

\footnotetext{
${ }^{12}$ See Zhang (2002).

${ }^{13}$ See Weeramantry (1997).

${ }^{14}$ See Wael (2003).

${ }^{15}$ See Alter (2004).

${ }^{16}$ See Rutherford (1644).

${ }^{17}$ See Montesquieu (1748). See also Tamanaha (2004).

${ }^{18}$ See Winks (1993); Billias (2011).

${ }^{19}$ See Lieberman (2005).

${ }^{20}$ See Adams (1779).
} 
the "Rule of Law" over and above "National Security or "National Interest" under the constitution of the Federal Republic of Nigeria.

\section{Rule of Law: A Necessary Part of Democracy}

In a democracy, the rule of law should be supreme to the capricious authority of any individual. The rule of law is the supreme check on political power used against people's rights. Without the regulation of state power by a system of laws, procedures, and courts, democracy could not survive. As the rule of law protects the majority from arbitrary power and tyranny, it must also protect the minority from arbitrary power and the "tyranny of the majority." 21 This scenario was further elegantly articulated in the words of John Adams when he said:

"Now to what higher object, to what greater Character, can any Mortal aspire, than to be possessed of all this [legal] Knowledge, well digested, and ready at Command, to assist the feeble and Friendless, to discountenance the haughty and lawless, to procure Redress of Wrongs, the Advancement of Right, to assert and maintain Liberty and Virtue, to discourage and abolish Tyranny and Vice.",22

As a corollary, John Lock said: "where-ever law ends, tyranny begins." ${ }^{23}$ The actual foundation of democracy is anchored on two pillars, the majority rule and the right of the minority protected. Notwithstanding that the majority rule, the rights and freedom of minority is preserved under the constitution. Although in making of policies, decisions or public issues, it is the majority that prevails but it covers the minority. In a democracy, it is what majority decides that wins, but it does not mean that the rights of the minority will be taken over. Essentially, the constitution protects the rights, liberties of the minority and allows them to have a voice in political decisions. One can become a minority for the reasons of gender, religious affiliation, ethnic origin, geographical location, sexual orientation, cultural minorities, language or even income level. Nonetheless, the government uses majority rule but give minority rights of equality protected under the constitution. The absence of the rule of law is likely to be mob rule or dictatorship. The rule of law should protect the majority from arbitrary power and tyranny of the majority against the minority. ${ }^{24}$ Aristotle was not a big fan of democracy because to him it is a bad form of government where everyone votes for everything which becomes tyranny of the majority and leaves minority at the whims of the masses. Democracy to him undermines the rule of law, whereas a functioning government shall be governed by laws. ${ }^{25}$ Incidentally, the minority rights' was protected under the UN's International Convention on Civil and Political Rights (“ICCPR"). ${ }^{26}$

\footnotetext{
${ }^{21}$ See McDuffie (2009).

${ }^{22}$ See Adams (1966).at 124; For further reading see Adams (2000).

${ }^{23}$ See Locke (1980) at 202.

${ }^{24}$ See Eze (1984).

${ }^{25}$ See Barnes (2005).

${ }^{26}$ See ICCPR (1966).
} 
When a society's legislation does not carry the interest of all the citizens along, it is malign and can often lead to revolution which no doubt breeds mob rule. In that case, some revolutionary thinkers regard "mob rule, or anarchism as the ultimate form of political and social justice." 27 Another name for mob rule is political chaos or violence which leads to dictatorship, in order words, the exercise of arbitrary power and refusal of private rights. Law is law when it is accepted by the people involved who are obligated to respect, keep and abide by it. These individuals submit to the notion that the breaking of such laws carries punishment administered by a constituted authority or law Courts in order to maintain peace and protect the lives and properties of the members of such a society. When the acceptability of the law is not unanimous by all and some minority voices dissents, it is no longer the law as it tends to be for a certain group of people only.

\section{Rule of Law and National Security in Nigeria}

A Nation is made up of the Citizens and these Citizens are the Nationals controlled by the law of the Nation which is enshrined in a legal document called the Constitution. The national security can only be invoked when the liberty of the citizens are at risk and a state of emergency is required or that the act perpetrated by an individual is felonious or an act of war against the country. At that point, it becomes a crime and an issue of national security, because the security of the nationals or citizens is likely to be breached. In such a case, it becomes the concern of the entire people who are the nationals. If the act perpetrated is of national security, it must follow due process of law. National security has no precise definition. It is a State-Centred concept in terms of military defence and security to protect national security by defending external aggression, maintaining Nigeria territorial integrity and securing its boarders from violation on land, sea or air. It is embedded within the Constitution and cannot be activated or invoked outside the Constitution of the land which is the pinnacle of rule of law. ${ }^{28}$ The call for National Security is relative depending on what constitutes national security and who interprets what a national security should be. Caution must be drawn here to discountenance any attempt to subjugate the rule of law under the aegis of national security because this will breed tyranny, anarchism or dictatorship which is alien to a democratic government. National security cannot be interpreted independently the constitution, it is within the constitution and can only be given the force of law by the constitution which is the supreme law of the state. The inclination to invoke national security in isolation of the rule of law could take us to Plato's warning in his very last book, where he summarised his understanding of law and said that:

"where the law is subject to some other authority and has none of its own, the collapse of the state, in my view is not far off; but if law is the master of the government and the government is its slave, then the situation is full of promise and

\footnotetext{
${ }^{27}$ See Ranney(1975) at 528.

${ }^{28}$ See Section 217 (2) (a) (b) Nigerian Constitution 1999 (as amended).
} 
men enjoy all the blessings that gods shower on a state."29 To Plato, law can eliminate possibility of tyranny in a democracy. He referred to the law as an "external authority" that exists as the "ally of the whole city.",30

Any suggestion of supremacy of the national security over the constitution is inconsistent with Section 14(1)(2)(b) (c) of the Constitution of the Federal Republic of Nigeria. Section 14(1) says:

"The Federal Republic of Nigeria shall be a State based on the principles of democracy and social justice." Section 14(2)(a) declares that "sovereignty belongs to the people of Nigeria from whom government through this Constitution derives all its powers and authority."

While Section 14(2)(b)(c) says that: "the security and welfare of the people shall be the primary purpose of government: and the participation by the people in their government shall be ensured in accordance with the provisions of this Constitution.",31

Section 14(1) automatically makes Nigeria a federation governed within the tenets of democracy and social justice. Whilst Section 14(2)(b)(c) makes it abundantly clear that every authority and power of the individual or government must be in accordance with the provisions of the constitution. The question now is, what is "National Security" or what constitutes "National Security" and who determines what constitutes "National Security" in the Nigerian context in accordance with the Nigerian Constitution. There have been different reactions and understanding of the concept "National Security" and "National interest." Nigerian former Inspector General of Police ("IGP"), Ibrahim Idris recently defined "national Security" and "national interest" and said that leaking his memo to acting President- Yemi Osinbajo on the siege to the National Assembly was " $a$ threat to national security. "32 The IGP for this reason attacked, harassed some key editorial staffs, detained reporter Samuel Ogundipe and froze his bank account. The question is, why and under what law were these actions justified within the parameters of the country's rule of law or could it be the invocation of a colonial law termed criminal sedition which provided that publication of truth, whether it is convenient or not, is a threat to "national security." 33 But in a democratic government, it is not the President, neither the IGP nor any of the ruling government bodies that determines what constitutes "threat to the national security and national interest," it is the exclusive reserve of the Courts in accordance with the rule of law enshrined in the constitution. President Muhammadu Buhari of Nigeria once said that the rule of law must be under the supremacy of the national security and national interest. ${ }^{34}$ This statement caused a stir from the Nigerian

\footnotetext{
${ }^{29}$ See Plato at 227.

${ }^{30}$ Ibid, at viii.

${ }^{31}$ See The Constitution, Federal Republic of Nigeria, (1999 as amended), Section 14. (1) and Sections (2) (a) (b) (c).

${ }^{32}$ See Ishiekwene (2018).

${ }^{33}$ See Halperin (2016).

${ }^{34}$ See Anaba, Akinrefon, Nochiri, Nwabughiogu, Yakabu \& Ojelu , (2018).
} 
lawyers on $28^{\text {th }}$ August 2018 at the Nigerian Bar Association ("NBA") Conference in Abuja.

Simply put, the rule of law comes second when national security and interest is threatened. The President was relying on the Supreme Court's decision delivered by Ibrahim Tanko Muhammad, Justice of the Supreme Court ("J.S.C") in Dokubo-Asari v Federal Republic of Nigeria, ${ }^{35}$ which according to him, has been settled by the apex Court of the land that national security and interest prevails over rule of law. It must be noted that in the case, it was for him to be granted bail and according to the rules of Courts, practice and procedure, bails are discretionary no matter the gravity of the offence. In Dokubo's case, he was accused of threatening to start a war against the country and the court decided that if he is granted bail, he may still carry out his threat and therefore refused him bail on grounds of national security and interest over and above his fundamental human rights, constitutional guaranteed personal liberty under Section 35(1) of the Constitution of Nigeria 1999 (as amended). It seems the Court did not consider that the law recognizes presumption of innocence of the individual, which is a known principle of law that an accused person is presumed innocent until proven guilty. ${ }^{36}$ The Court however took the view that "It is better to preserve the liberty of many than a few antagonists to the law in the face of felony." ${ }^{37}$ If caution is not taken in the interpretation of national security over and above the rule of law, it could lead to abuse of power which can come in the form of Executive Orders to matters already in court or arbitrary arrest of the citizens in the name of threat to national security or national interest. Where such orders are given or arbitrary arrest carried out against the citizens, it will amount to breach of the principle of separation of powers. Executive Orders become permissible if it is issued for good governance and to direct the conscientious running of the government. It should not be to encroach or usurp the reserved powers under the constitution for other arms of government. Under a democratic government, Executive Orders are well guided by the rule of law, otherwise, it becomes a decree-making which can be termed autocracy.

In Marx's critique of Hegel's legal sophistry, ${ }^{38}$

"a constitution that expresses social form to reason must be the outcome of selfconscious human beings acting and living as members of a self-legislated polity "[...]" this polity can be nothing other than a "true democracy.",39

To Marx, the people are the advancement of the society and the people are the constitution. The human rights and national security are contiguous and cannot be competing with each other. The practice of human right in any society will eliminate issues of national security as both goals are complementary. These are multiplicities of norms which forms the basis of a community's legal system.

\footnotetext{
${ }^{35}$ See Dokubo-Asari v Federal Republic of Nigeria (2007). 12 NWLR (PT 1048) 320 at 357 para $A-C$.

${ }^{36}$ See Enebeli $v$ Chief of Naval Staff (2000). 9 N.W.L.R (Pt 671) 119 at 124-125

${ }^{37}$ See Dokubo-Asari v Federal Republic of Nigeria (2007). 12 NWLR (PT 1048) 320 at 357.

${ }^{38}$ See Marx \& Engels (1975).

${ }^{39}$ See Alexandros (2018).
} 
These legal norms are formed through other norms and not independent of each other. $^{40}$ The decision of the Nigerian apex Court has not rendered the supremacy of the rule of law moribund when it contradicted Citizens liberty guaranteed under the constitution, but could have been reached as a matter of discretionary circumstances to dispense justice based on reasoning not legalism.

\section{Freedom of Press in Nigeria}

One of the latest Rule of Law abuse in connection with 'National Security' has been orchestrated in the recent arrest and re-arrest of Omoyele Stephen Sowore, a journalist, owner and publisher for online news agency Sahara Reporters ${ }^{41}$ which demonstrates a clamp down on the freedom of press in Nigeria. Sowore and Olawale Adebayo Bakare (aka Mandate) were arrested in Nigeria on the $3^{\text {rd }}$ of August 2019 charged with attempt to overthrow the government of Nigeria using a protest tagged "Revolution Now" in a bid to demand good governance for Nigerians. The arrest of Sowore and Bakare took place the same date the protest was scheduled to take place. Accordingly, they were detained by State Security or Department of State Service ("DSS") punitively for weeks without bail. On 24 September 2019, they were arraigned before a judge sitting in Abuja High Court and was granted bail on Seven count charge marked $\mathrm{FHC} / \mathrm{ABJ} / \mathrm{CR} / 235 / 2019$ which ranges from treasonable felony to overthrow the administration of the Government contrary to section 516 of the criminal Code Act Cap C38 Laws of the Federation of Nigeria, 2004, and punishable under the Act; charged with crimes related to transfer of funds contrary to Section 15(1) of the Money Laundering (Prohibition) Act, 2011 punishable under the same Act; and "Cyber-Stalking" contrary to section 24 (1) (b) of the Cybercrimes (Prohibition, Prevention) Act, 2015, punishable under the same Act. ${ }^{42}$ The government ignored the bail granted to Sowore by a Court of competent jurisdiction in Federal Capital territory Abuja and took Sowore to a different High Court where he was charged with the same offences. On October $4^{\text {th }} 2019$, Sowore was granted bail by a different judge under stringent conditions and on November 6, 2019, his release from the DSS was ordered by the Court after perfecting his bail conditions.

Unfortunately, Sowore was not released and an attempt by activist's demonstration at State Security headquarters Abuja for Sowore's release met an open Gun fire and physical assaults by DSS on the protesters. It is unclear if the detention of Sowore is related to his profession as a journalist or his political activism since he took part in the last 2015 presidential election as a Presidential candidate but lost. It is difficult to say that his arrest and detention was in connection with the Public Order Act, an Act of National Assembly, deriving its powers from Section 45(1) of the 1999 Constitution of Nigeria and became an existing law of Nigeria under Section 315 of the Constitution. Notably, the Nigeria

\footnotetext{
${ }^{40}$ See Cotterrel (2001).

${ }^{41}$ See Ikenwa (2019).

${ }^{42}$ See Nnochiri (2019).
} 
law of Public Order $\mathrm{Act}^{43}$ is provided to encourage peaceful conduct of meetings, public assemblies and processions. In order to convene a public gathering or conduct procession, a license must be sought and obtained from the Police by the conveners. The process of obtaining this license was cumbersome and led to Police continual illegal arrest of citizens conducting public protest and claim that the citizens did not obtain license from the Police and/or Governor to embark on such rallies, assemblies or protests. Thus, the implementation of this Public Order Act became questionable and led to Civil liberty Organizations suing for a repeal of the Act to protect the Citizens constitutional rights of association and assembly. The legality of civil protests and demonstrations in Nigeria is enshrined in the Nigerian Constitution to protect freedom of expression, assembly and peaceful protests. Interestingly, Section 39 of the Constitution of the Federal Republic of Nigeria (CFRN) 1990, provides that:

"Every person shall be entitled to freedom of expression; every person shall be entitled to own, establish and operate any medium for the dissemination of information, ideas and opinions."

Similarly Section 40 of the 1999 Nigerian Constitution, (as amended) provided that:

"Every person shall be entitled to assemble freely and associate with other persons, and in particular he may form or belong to any political party, trade union or any association for the protection of his interest [...]".

Accordingly, the Public Order Act was quashed in 2007 by Court of Appeal Abuja Division in IGP $v$ ANPP and 11 Others. ${ }^{44}$ The respondent in this case challenged the constitutionality of the Public Order Act which required a permit or license of the Police and/or Governor before assemblies, procession and rallies can be held. The Court of Appeal - the Abuja Division Per Adekeye JCA held that:

"[T]he Constitution should be interpreted in such a manner as to satisfy the yearnings of the Nigerian society. The 1999 Constitution is superior to other legislation in the country and any legislation which is inconsistent with the Constitution would be rendered inoperative to the extent of such inconsistency. Section 1(2), (3), (4), (5) and (6) and sections 2, 3 and 4 of the POA are inconsistent with the constitution - they are null and void to the extent of their inconsistency.

It is evident from recent arrests and rearrests of citizens exercising their constitutional rights under the Sections 39 and 40 of the 1999 Constitution of Federal Republic of Nigeria, that the Police has refused to implement the Court ruling on the Public Order Act, perhaps because the Nigerian Police is more interested in protecting the government than the rights of the citizens. However, in order to avert a repeat of Sowore's incident and to prevent critics against

\footnotetext{
${ }^{43}$ See Nigeria Public Order Act (1990). Laws of the Federation of Nigeria, Chapter 382.

${ }^{44}$ See IGP v ANPP and 11 Others (2007). 18 NWLR (Pt 1066) 457 CA.

${ }^{45}$ Ibid.
} 
government authorities, new bills were recently formulated and brought before the Nigerian Senate to be passed into law. The bills proposed are for National Commission for the Prohibition of Hate Speech bills and the Protection from Internet Falsehood and Manipulation and Related offences bills that could impose death sentence or long term imprisonment for accused persons if convicted. ${ }^{46}$ Essentially, this bill will be in breach of freedom of expression and the right to free speech which are recognised both under National and International law.

Amnesty International reacting to the bill said:

"Social media is one of the last remaining places where Nigerians can express their opinions freely. The harassment of journalists and bloggers and the introduction of the Cyber Crimes Act have already shrunk the civic space and created a climate of fear. We are urging the Nigerian authorities to drop these bills, which are open to vague and broad interpretations and impose incredibly harsh punishments simply for criticizing the authorities. ",77

\section{Hate Speech and International Law}

Hate Speech according to Max Planck Encyclopedia of Comparative Constitutional Law ["MPECCoL"], consists of verbal or non-verbal communication that involve hostility directed towards particular social groups, most often on grounds of race and ethnicity (racism, xenophobia, anti-Semitism, etc., gender (sexism, misogyny), sexual orientation (homophobia, transphobia), age (ageism), disability (ableism) etc. ${ }^{48}$ Hate speech is not regulated under liberal democracies like America as right to free speech is enshrined in the American Constitution and protected under the First Amendment. In support of free speech ${ }^{49}$ as it relates to democratic citizenship vis-à-vis hate speech, it should be viewed in relation to equal respect for all citizens and respect to the rule of law. This is an essential approach as we are not dealing with hate speech in isolation of free speech. Generally, a right to free speech was not recognised by common law.

As United Kingdom has no written constitution, the only constitutional protection created to freedom of expression which applied to only Members of Parliament ("MPs") 50 , was in the Bill of Rights (1689) at the advent of the Human Rights Act 1998. ${ }^{51}$ A workable compromise that gives due cognisance to a variety of values must be taking in to consideration especially when free speech is to be diluted for the utter implementation of hate speech with regards to national security. John Milton argued that freedom of speech does not only mean right to express or disseminate information and ideas, it also includes the right to seek

\footnotetext{
${ }^{46}$ See Ross, Reynolds \& Trager (2018).

${ }^{47}$ See Bakare (2019).

${ }^{48}$ See Belavusau (2018); Belavusau (2013); Dworkin (1992).

${ }^{49}$ See Van Mill (2018); Sorial 2012).

${ }^{50}$ See Bill of Rights, Chapter 2, Article 9 (1689). States: "That the freedom of speech and debates or proceedings in Parliament ought not to be impeached or questioned in any court or place out of Parliament."

${ }^{51}$ See Human Rights Act. (1998). UK Public General Acts,(1998) Chapter. 42.
} 
information and ideas; the right to receive information and ideas; and the right to impart information and ideas. The harm principle proposed by English philosopher John Stuart Mill states that people should be free to express themselves or act as they wish unless such action or free speech will cause harm to others or somebody else. This principle is anchored on the tenets of political philosophy of liberalism. The harm principle is not contemplated to direct the actions of individuals, but to unfree the quantum of criminal law and government interventionism on personal liberty. The question remains, does the speech pose an imminent danger or does it incite violence? It is Mills' view with many politicians, philosophers and legal theorists that the disapproval of social action of a person is not enough to justify government intervention, unless it harms someone. John Stuart Mills 'harm principle' views freedom of speech as a non-absolute right and presents a way by law in which power can be legitimately exercised by society over the individual. ${ }^{52}$ Mill opined that the only grounds to which power can be justifiably used over any members of a civilised society, against his will, is to avoid harm to others. That is to say that the actor cannot be absolved from the rightful exercise of power over him because of his own good, whether physical or moral as it is not enough justification. ${ }^{53}$ The limitation of freedom of speech sometimes waters down the essence of freedom of speech which protects and upholds peoples' rights to express themselves against outrageous, racists, unpopular or unorthodox practices that goes on in the society. It is understandable if freedom of speech is limited in order to avert criminality or protect the rule of law especially when such speech poses an imminent danger or inciting violence against somebody. ${ }^{54}$ Ordinarily, freedom of speech should be upheld in the law of the society to embolden individuals to speak out without fear or favour against the ills, acts and practices of the society or government which adversely affects them or the society. ${ }^{55}$ In line with the foregoing, the government of Nigeria has proposed a regulation of the social media and the information shared on them; but the bill was withdrawn for reasons of conflict with the laws of the federal Republic of Nigeria. Section 39 (1) of the Constitution of Nigeria states clearly that:

"Every person shall be entitled to freedom of expression, including freedom to hold opinion and to receive and impart ideas and information without interference."

Essentially, International law and standards does not condone hate speech, but prohibits the advocacy of hate speech. On the other hand, International law and standards prohibits divisive speeches of hatred that could be deemed to be hostility or violence, or incitement to discrimination. Hate speech may be harmful, but if it does not reach the threshold of incitement, it may not be prohibited by International law. Hate speech laws could be within the governing laws of nation states but must be clearly formulated as carrying a lesser weight to incitement. By

\footnotetext{
${ }^{52}$ See Skorupski (1998).

${ }^{53}$ See Mill (1859).

${ }^{54}$ See Hamburger (1985).

${ }^{55}$ See Belavusau (2017).

${ }^{56}$ See The Constitution of the Federal Republic of Nigeria, Section 39(1) (1999 as amended).
} 
and large, such laws shall also be in tandem with the freedom of expression rights, and shall be consistent with these rights recognised in International Law and Regional Human Rights Law and enshrined in Article 19 (1,2 and 3) of the International Covenant on Civil and Political Rights (CCPR), ${ }^{57}$ Article 10 of the European Convention on Human Rights(ECHR), ${ }^{58}$ Article 13 of American Convention on Human Rights (ACHR), ${ }^{59}$ and Article 9 of the African Charter on Human and Peoples Rights (ACHPR). ${ }^{60}$ The right to freedom of Speech is also recognised as a human right under Article 19 of the Universal Declaration of Human Rights (UDHR). ${ }^{61}$ Nonetheless, freedom of speech aforesaid, is not absolute, as it has limitations and boundaries when it conflicts with other peoples' rights and freedoms like in the cases of libel, obscenity, pornography, slander, sedition, incitement, non-disclosure agreements, rights to privacy, dignity, perjury, fighting words, classified information, intellectual property rights such as copyright violations, trade secrets and public security. These limitations are articulated in terms of harm principle proposed by John Stuart Mill 'On Liberty', which implies that:

"the only purpose for which power can be rightfully exercised over any member of a civilized community, against his will, is to prevent harm to others. "62

But the harm to others has to be specified as to what constitutes harm to others and what does not. ${ }^{63}$ In most cases, we are likely to fail in this task as it could lead to a slippery slope. ${ }^{64}$ The inevitable consequences of limiting speech could end up to tyranny. Nevertheless, to allow government interventions on free speech could slide into censorship of anarchy or a state of life "solitary, poor, nasty, brutish and short" as described by Hobbes in Leviathan. ${ }^{65}$ The free speech should not require such strong barrier as the harm principle to limitation of free speech. The U.K. Public Order Act 1986 states that:

"A person is guilty of an offence if he displays any writing, sign or other visible representation which is threatening, abusive or insulting, within the hearing or sight of a person likely to be caused harassment, alarm or distress thereby. ",66

\footnotetext{
${ }^{57}$ See ICCPR (1966) Article 19.

${ }^{58}$ See ECHR (1953) Article 10

${ }^{59}$ See ACHR (1969) Article 13

${ }^{60}$ See African Charter on Human and Peoples' Rights (adopted 27 June 1981, entered into force 21 October 1986) (1982) 21 ILM 58 (African Charter), article 9

${ }^{61}$ See Universal Declaration of Human Rights(1948). Adopted 10 December 1948 UNGA Res 217 A (III) (UDHR) article 19. Article 1 of the UDHR

${ }^{62}$ See Mill (1978) at 9.

${ }^{63}$ See James v Commonwealth of Australia (1936). UKPCHCA 4 AC 578 at 627:

${ }^{64}$ See Schauer (1986); Schauer (1982).

${ }^{65}$ See Hobbes (1986).

${ }^{66}$ See The U.K. Public Order Act (1986). Section 5 (1) (b) as amended 1994; Van Mill (2017). For a Court decision angle, see: Mark Anthony Norwood v. Director of Public Prosecutions (2003). EWCH 1564 (QB) para. 16.
} 
No democracy can survive without its tenets of respect for the rule of law, judicial independence, due process, media freedom and of course political freedom. The actions of the ruling government on human rights violations is clearly in breach of the Section 143 (11) of the 1999 Constitution of Nigeria (as amended) and can be termed a "gross misconduct" which could attract impeachment process. Nonetheless, Omoleye Sowore and Sambo Dasuki were released on $24^{\text {th }}$ December 2019 by the federal government of Nigeria after threatening pressures from International Community, particularly, the involvement of America ${ }^{67}$ and NGO's like Amnesty International against the violation of Court Orders and infringement of rule of law by Nigerian government. Amnesty International tweeted and said:

"The attempted abduction and eventual rearrest of prisoner of conscience Omoyele Sowore and Olawale Bakare, including the desecration of the Nigerian judiciary by SSS officials tells a bigger story of impunity and flagrant disregard for the rule of law by the Nigerian government.

The question still remains whether the government of Nigeria will now start adhering to the rule of law or is it just bowing to the pressure of the International Community. The release of Sowore and Dasuki is just a tip of the iceberg considering the plethora of violated Court Orders or deluge of journalists being detained for speaking out, political activists and individuals who in one way or the other are still in detention. A lot of Nigerian Citizens are being incarcerated because they vented out their anger or opinion against the government maladministration and clamp down on rule of law. Benjamin Franklin warned that the citizens should not be forced to give up their freedoms and he said:

"In those wretched countries where a man cannot call his tongue his own, he can scarce call anything his own. Whoever would overthrow the liberty of a nation must begin by subduing the freeness of speech. "69

\section{Synthesis of National Security}

In a democratic government like Nigeria, what constitutes national security will be determined by a court of competent jurisdiction. It is within the ambits of the legislative body of the government to make the law and define what constitutes national security, while the judicial body of the government interprets what constitutes national security and the Executive arm of government implements and enforces it. It will amount to usurpation of power for one arm of the government to exceed its power or use its power to intimidate or frustrate another arm of government in the day to day administration of the country. In order to curtail the powers of the three tiers of government, there must be respect to each arm, separation of powers and checks and balances to avoid arbitrary use of power.

\footnotetext{
${ }^{67}$ See Maclean. (2019).

${ }^{68}$ See Amnesty International Nigeria (2019).

${ }^{69}$ See Franklin (1722).
} 
Separation of powers was coined by French political Enlightenment thinker Baron de Montesquieu as a model for democratic governance. However, it was first developed by the Greeks and gained notoriety by Roman Republic who adopted it in the constitution of the Roman Republic. ${ }^{70}$ The intent of the proponents of separation of powers is for it to protect democracy and prevent tyranny. The idea behind separation of powers is to prevent so much power on a single person or group as they are likely to become dangerous to citizens. Therefore separation of powers limits arbitrary use of powers by any arm of government and also helps to check corruption and unlawful actions against the citizens whom the government ordinarily supposed to preserve. Separation of power is the principle that requires the three tiers of government to undertake independent yet interdependent roles that must remain separated, with systems of understandable checks and balances on no account should all power rest with a single arm of government, neither should any single arm of government dominate authority. Nevertheless, authority should be limited, apportioned and checked among the three branches of government. A nation can only achieve these if only the rule of law is supreme over and above any other laws within the confines of the constitution.

In support of the supremacy of the rule of law, Justice Walter Onnoghen JSC (as he then was) in AG Abia State v Attorney General Federal Republic of Nigeria, said that:

"where the rule of law reigns, political expediency ought to be sacrificed on the altar of the rule of law so as to guarantee the continued existence of democratic institutions fashioned to promote social values of liberty, orderly conduct and development, particularly in a republic founded on the principle of federalism where power is further apportioned among three arms of government, termed legislature, Executive and judiciary. See Sections 4, 5 and 6 of the 1999 constitution $^{71}$ (as amended).,"72 of law:

Besides, the learned Justice Kayode Eso ("JSC") had this to say about the rule

"The rule of law knows no fear, it is never cowed down; it can only be silenced by the only arm that can silence it, it must be accepted in full confidence to be able to justify its existence. It is the duty of the government to allow the law to take its course or allow the legal and judicial process to run its full course.",73

It is trite that the three arms of government are equal partners without any usurpation of power from one to another. Eso, JSC noted in Ojukwu v Military Governor of Lagos State that:

\footnotetext{
${ }^{70}$ See Wade \& Forsyth (2009). See also Takwani (2004).

${ }^{71}$ See The Constitution of the Federal Republic of Nigeria (1999). Chapter 1, Part II, Sections 4,5, and 6 (Powers of the Federal Republic of Nigeria).

${ }^{72}$ See A.G Abia State v Attorney General Federal Republic of Nigeria (2006) 16 NWLR, PT 1005.

${ }^{73}$ See Saidu Garba v Federal Civil Service Commission (1988) 1NWLR (pt.71). P. 449.
} 
"Under the Constitution, the Executive, the Legislature and the Judiciary are equal partners in the running of a successful Government. The powers granted by the Constitution to these organs are classified under an omnibus umbrella known under Part 11 of the Constitution of Federal Republic of Nigeria. The organs wield these powers and one must never usurp the power of the other or else there is chaos." 74

The Court warned in A.G. Federation v ANPP (2003), that the Constitution should not be given a political interpretation, matters should be resolved without partisan interest invoked in the interpretation of the constitution or such political interpretation will open doors to bad governance, misrule of the masses and the State. ${ }^{75}$ The rule of law must not at any event be jettisoned on the altar of national security but shall be guarded within the provisions of the law. The rule of law is the Grundnorm ${ }^{76}$ of any society and remains the primus inter pares in all laws of the country.

The subjugation of the rule of law to national security will breed anarchism because the coercive power of a State is empowered by law. Lawlessness is a situation where the law ceases to work, citizens obeys not the State and does not respect the rights of others. This no doubt will be the antithesis of Hobbesian state where life was:

"continual fear, and danger of violent death; and the life of man solitary, poor, nasty, brutish and short.",77

Hobbes, warned against statecraft, security and rule of law in a society. He cogitated that in such a world of violence and horror, can we stop ourselves from descending into anarchy. Hobbes, in his book The Leviathan postulated that man is naturally evil, a derivative from God in the book of Genesis 6:5, where he said:

"And God saw, that the wickedness of man was great in the earth, and that every imagination of the thoughts of his heart was only evil continually.",78

Hobbes argues, that man's life in a state of his nature, is a life of no control and miserable. Hobbes implied that man's innate tendency is to accumulate power and wealth and use it to lord over others. He suggested that man's attitude is only tamed by law which helps to regulate his hidden evil nature, otherwise if man finds himself in an environment where there are no laws, the true nature of man will take over him by way of war, violence, greed for power for self against others. He posited that what holds man's evil nature is fear of death or punishment by the law. Hobbes solution to mankind in a circle of selfish nature is the presence of absolute sovereignty to regulate the conduct of man in the society. To Hobbes, in the absence of the sovereign, there will be no right or wrong, every act is acceptable, because there is no justice or injustice, no societal values, liberties will

\footnotetext{
${ }^{74}$ See Ojukwu v Military Governor of Lagos State (1986) INWLR (18) P. 62.

${ }^{75}$ See Attorney General Federation v ANPP (2003) FWLR (pt. 169), P. 703 at 878.

${ }^{76}$ See Kelsen (1945).

${ }^{77}$ See Hobbes [1651], Hobbes (1962), and Hobbes (2017).

${ }^{78}$ See Hobbes [1651]; Hobbes (1962). Ch. 13 p.92; Hobbes (2017).
} 
be non-existent and man face commodious living. ${ }^{79}$ Hobbes pontification is that the ideal situation is to draw a contract for mankind with "absolute power" given to the sovereign to regulate the activities of the mankind to obey the contract with fear of punitive repercussions expressed against non-performance of the contract. Hobbes understanding of sovereignty is not necessarily a person but the law giver, a King or person in a position of deity or custodian of the law that can unleash punishment if there is disobedience to the law. ${ }^{80}$

Hobbes ideal of social contract is to end dictatorship of the Leviathan to create peaceful coexistence of the citizens to ensure respect and development of human society. ${ }^{81}$ The absolute sovereignty in a modern day democracy is the constitution of a country which is the overarching document that personifies a nation as sovereign. The rule of law is the principles of law, supreme and above any individual or government. Every democracy should strive to institute three objectives to enable the attainment of rule of law in the society. There must be symmetry between the legal structure in the short term and long term; between the citizens and the society; and to ensure the protection of minority rights. The presence of rule of law in any society leads to good governance because such laws must be implemented and enforced fairly repeatedly in a crystalline manner, otherwise, such laws becomes obsolete, archived, jettisoned laws or regrettably oppressive weapons. Additionally, there must be avoidance of fusion of powers through the institution of an independent Judiciary and the decisive fight against the endemic corruption in the community. Secondly, the law should be able to create a short term and long term plan between the concerns of the individuals and the interest of the society in order to attain recognition for Human Right and dependability. Thirdly, the interest of the minority shall be protected with the short term and long term legal plan of the country.

The law should not be used as a tool for persecution of opposition members and perceived political opponents. The government agencies originally created with good intentions should not lose its essence or metamorphosed into a draconian agency with little regard to the rule of law and human rights. Such governmental agencies shall not be used as a media show to intimidate or embarrass or disparage reputation of key opposition members or government agencies deemed to be averse to the whims and caprices of the electoral goals of the party in power. Placing the national security above the constitution will create consequences of arbitrariness since the rule of law is the antithesis of arbitrariness. After all, who invokes what constitutes National Security in Nigeria, in most cases, it is the country's Chief Executive. He can pick and choose who to arrest or indict especially when the unprotected actor is trying to open "Can of Worms" in his administration. Nigeria can be described as the Animal Farm of George Orwell where all the animals were said to be equal but some are more equal than others. ${ }^{82}$ Nonetheless, the Supreme Court of India says that the essence of rule of law is to

\footnotetext{
${ }^{79}$ See Tuck (1996); Hobbes: (1651).

${ }^{80}$ See Tuck (1996); Hobbes: (1651) at 268-269

${ }^{81}$ See Bewaji (2016).

${ }^{82}$ See Orwell (1946).
} 
protect individual liberty against arbitrary exercise of power at any place and time. $^{83}$

\section{Conclusion}

This treatise has not left democracy in isolation of the rule of law, both are interlaced as core universal values of a civilized world. This paper has explored the rule of law as inalienable rights of the citizens, a paramount factor in constitutionalism, supreme, or impeccable principles of law of any given society. This paper has questioned the possible imposition of the national security or national interest in utter disrespect to the rule of law in Nigeria. Nonetheless, the author has juxtaposed the rule of law with national security and has taken a view that the national security is embedded in the rule of law and cannot override the supremacy of the constitution. The implementation of rule of law will ensure peace, rapid economic growth, development, respect to human rights, respect to civil liberty, freedom of press and the restoration of human dignity within Nigerian populace.

\section{References}

Adams J. (1779). The Report of a Constitution or Form of Government for the Commonwealth of Massachusetts, 28-31 October, Harvard University Press

Adams, J. (1966). Diary and Autobiography of John Adams [1759]. (Edited by L. H. Butterfield). Cambridge, MA: The Belknap Press of Harvard University Press.

Adams, J. (2000). The Revolutionary writings of John Adams. (Edited by C. Bradley Thompson). Indianapolis: Liberty Fund.

Alexandros, C. (2018). True Democracy' as a Prelude to Communism. The Marx Democracy, Palgrave Macmillan.

Alter, R. (2004).The Five Books of Moses: A Translation with Commentary. New York, NY: W.W. Norton \& Company.

Aristotle (c. 350 BC). The Politics [c. 350 BC], (Stephen Everson trans) (1988). Cambridge: Cambridge. University Press, Politics 3

Bakare, S. (2019). 'Nigeria: Bills on hate speech and social media are dangerous attacks on freedom of expression' in Amnesty International Nigeria (4 December).

Barnes, J. (2005). 'Aristotle and Political Liberty' in Richard Kraut \& Steven Skultety (eds.) Aristotle's Politics: Critical Essays pp. 185-201. New York. NY: Rowman \& Littlefield.

Belavusau, U. (2013). Freedom of Speech: Importing European and US Constitutional Models in Transitional Democracies . Routledge.

Belavusau, U. (2017).Hate Speech. Max Planck Encyclopedia of Comparative Constitutional Law. Oxford University Press.

Bewaji, L.A.I. (2016). The Rule of law and Governance in Indigenous Yoruba Society: A Study in African Philosophy of Law. Lanham, Md: Lexington Books.

${ }^{83}$ See Raman Dayarem Shetty v International Airport Authority of India. (1979). Air 1628, 1979 SCR (3) 1014 
Vol. 7, No. 2 Igwe: The Rule of Law and National Security in Nigerian Democracy...

Billias, G.A. (2011). American Constitutionalism heard round the world, 1776 - 1989: a global perspective. New York: New York University Press.

Bingham, T. (1949) .The Rule of Law. London: Penguin Books

Black, A. (2009). World History of Ancient Political Thought. Oxford: Oxford University Press.

Cicero, M.T. (106-43 BC) Murder Trials. Penguin Classics. (Translated by Michael G.H.) (1975). London: Penguin Books.

Cooper, J. \& D. Hutchins (1997). On Complete Works by Plato. Indianapolis/Cambridge: Hackett company Publishing Inc.

Cotterrel, R. (2001). Jurisprudence. $2^{\text {nd }}$ ed. Butterworths Lexis Nexis.

Dalter, K. (2016). The Power Paradox: Does Absolute Power Corrupt Absolutely. London: Penguin Press.

Dworkin, R. (1992). 'The Coming Battles over Free Speech' in The New York Review, June 11, 1992 issue/

Eze, O. (1984). "Human Rights in Africa: Some Selected Problems." Lagos: Nigerian Institute of International Affairs.

Franklin, B. (1722). "US Founding fathers." (1706-1790) Dogwood Papers. Available at: http://libertytree.ca/quotes/Benjamin.Franklin.Quote.4003.

Halperin, T. D. (2016). The Alien and Sedition Acts of 1798: testing the Constitution. John Hopkins University Press.

Hamburger, P.A. (1985). 'The Development of the Law of Seditious Libel and the control of the Press' in Stanford Law Review 37(3):661-765.

Hobbes, T. [1651]. Leviathan or the Matter, Forme and Power of a Commonwealth Ecclesiastical and Civill, London: London, printed for Andrew Crooke, at the Green Dragon in St. Pauls Church-yard.

Hobbes, T. (1986). Leviathan'. Edited by C.B. Macpherson, London: Penguin Books.

Hobbes, T. (2017). Leviathan. Edited by Christopher Brooke, London: ed. Penguin Classics.

Hobson, C. (1996). The Great Chief Justice: John Marshall and the Rule of Law. Kansas: University Press of Kansas .

Ikenwa, C. (2019). 'Omoyele Sowore Biagraphy \& Network' in Nigerian Infopedia, December 6.

Ishiekwene, A. (2018). 'Lawyers, Buhari and the ruins of Law' in Nigerian Vanguard Newspaper, August 31.

Kelsen, H. (1945). General Theory of Law and State. (Translated by Anders Wedberg). Cambridge: Harvard University Press.

Lieberman, J. (2005). A Practical Companion to the Constitution. California: University of California Press.

Locke, J. (1980). Second Treatise of Government. Indianapolis: Hackett Publishing Co. Inc.

Machiavelli, N. (1882).The Historical, Political, and Diplomatic Writings of Niccolo Machiavelli. Translated by Christian, E. Detmond). Volume 2. Boston: J.R. Osgood and Company Inc.

Maclean, R. (2019). 'Nigeria Releases Leading Critic on Bail After a Campaign on Ocean Away' in. New York Times 24 December. Available at: Nigeria Releases Leading Critic on Bail After a Campaign an Ocean Away - The New York Times (nytimes.com)

Marx, K \& F. Engels (1975). In Marx \& Engels Collected Works.(1975) Vol. 3. Karl Marx March 1843- August 1844. Lawrence \& Wishart. Independent Radical Publishing. 
McDuffie, N. (2009). 'Majority Rule with Respect to Minority Rights' 16 February. http://www.associatedcontent.com/article/1016764/majority_rule_with_respect_to_m inority_pg3

Mill, J.S. (1859). On Liberty. Introductory (2001). Batoche Books: Kitchner Ontario, Chapter 1, pp. 1-18.

Mill, J.S. (1859). On Liberty (1978). Indianapolis: Hackett Publishing.

Montesquieu, C. (1748). The Spirit of the Laws. Anne M. Cohler, Basia Carolyn Miller \& Harold Samuel Stone (eds) (1989). Cambridge: Cambridge University Press.

Nnochiri, I. (2019). 'FG slams 7-count money laundering, conspiracy charges against Sowore'. Vanguard Newspaper. September

Oakeshott, M. (1962). Rationalism in Politics and Other Essays. London: Melthuen and Co.

Plato (Aristocles). The Republic 227. (c 360 B.C.) Translated by Francis, M. Cornford (1951). Oxford: Oxford University Press.

Ranney, A. (1975). The Governing of Men. London: The Dryden Press.

Ross, S.D., Reynolds. A.L. \& R.E. Trager (2018). The Law of Journalism and Mass Communication, $7^{\text {th }}$ ed. Thousand Oaks, Calif.: Sage Publications Inc.

Rutherford, S. (1644). Lex, Rex, or The Law and the prince; a dispute for the just prerogative of king and people; containing the reasons and causes of the defensive wars of the kingdom of Scotland, and their expedition for the aid and help of their brethren of England. Reprinted in 1843 by Edinburgh: A. Murray.

Schauer, F. (1982). Free Speech: A Philosophical Enquiry. Cambridge: Cambridge University Press.

Schauer, F. (1986). 'Slippery Slopes' in Harvard Law Review 99 (2):361-383.

Skorupski, J. (1998). 'Liberty and democracy' In Mill, John Stuart (1806-73)' in Routledge Encyclopedia of Philosophy, Taylor and Francis. Available at: https:// www.rep.routledge.com/articles/biographyical/mill-john-stuart-1806-73/v-1/ section/liberty-and-democracy

Sorial, S. (2012). Sedition and the Advocacy of Violence: Free Speech and CounterTerrorism. London: Routledge.

Takwani, C.K. (2017). Lectures on Administrative Law. 6th ed.. Lucknow: Eastern Book company

Tamanaha, B. Z. (2004). On the Rule of Law: History, Politics, Theory. Cambridge: Cambridge University Press.

Tuck, R. (1996). Hobbes: Leviathan. (1651). Revised Student Edition. Cambridge Texts in the History of Political Thoughts. Cambridge: Cambridge University

Van Mill, D. (2017). Free Speech and the State, An Unprincipled Approach. Palgrave Macmillan.

Van Mill, D. (2018). 'Freedom of Speech' in Edward N. Zalta (eds.). The Stanford Encyclopedia of Philosophy. https://plato.stanford.edu/archives/sum2018/entries/ freedom-speech/

Wade, H.W.R. \& C. F Forsyth, (2009). Administrative Law. 10 ${ }^{\text {th }}$ eds. Oxford: Oxford University Press.

Wael, H. (2003). The Impossible State: Islam, Politics and Modernity's Moral Predicament. New York, NY: Columbia University Press.

Weeramantry, C. (1997). Justice without Frontiers. Furthering Human Rights. Kluwer Law International.

Winks, R.W. (1993). World Civilization: a brief history. $2^{\text {nd }}$ ed. San Diego, CA: Collegiate Press.

Wormuth, F. (2010). The Origins of Modern Constitutionalism. New York, NY: Harper and Brothers. 
Vol. 7, No. 2 Igwe: The Rule of Law and National Security in Nigerian Democracy...

Zhang, X. (2002). 'On Two Ancient Chinese Administrative Ideas: Rule of Virtue and Rule by Law' in Culture Mandala: Bulletin of the Centre for East-West Cultural and Economic Studies. Article 7, Volume 5 Issue 1.

\section{Cases}

A.G Abia State v Attorney General Federal Republic of Nigeria (2006) 16 NWLR, PT 1005.

Alhaji Mujahid Dokubo-Asari v Federal Republic of Nigeria (2007). S.C. 208/20006 NGSC 106, 8 June.

Dokubo-Asari v Federal Republic of Nigeria (2007). 12 NWLR (PT 1048) 320 at 357 para A-C.

Enebeli $v$ Chief of Naval Staff (2000). 9 N.W.L.R (Pt 671) 119 at 124-125

Garba, S. v Federal Civil Service Commission (1988) 1NWLR (pt.71). p. 449.

IGP v ANPP and 11 Others (2007). 18 NWLR (Pt 1066) 457CA. Available at: https//jud gements.lawnigeria.com/2018/05/04/3plr-inspector-general-of-police-v-all-nigeria peoples-party-ors/. [19 September 2020].

James $v$ Commonwealth of Australia (1936). UKPCHCA 4 AC 578.

Mark Anthony Norwood v Director of Public Prosecutions (2003). EWCH 1564 (QB) para. 16.

Ojukwu v Military Governor of Lagos State (1986) 1NWLR (18) P. 62.

Raman Dayarem Shetty v International Airport Authority of India (1979). Air 1628, 1979 SCR (3) 1014

\section{Legislation, Conventions, Charters}

African Charter on Human and Peoples' Rights (adopted 27 June 1981, entered into force 21 October 1986) (1982) 21 ILM 58 (African Charter), article 9.

Amnesty International Nigeria (2019). Tweet @ Amnesty Nigeria December 6, available at: https://twitter.com/AmnestyNigeria/status/1202998312812589056

Constitution, Federal Republic of Nigeria, [Nigeria], Act No. 24, 5 May (1999 as amended).

ECHR -uropean Convention on Human Rights (ECHR) Article 10, European Court of Human Rights. Updated 31 August 2020. Available at: https://www.echr.coe.int/ documents/convention_eng.pdf

Human Rights Act (1998). UK Public General Acts (1998) Chapter. 42. Available at: http://www.legislation.gov.uk/ukpga/1998/42/contents

ICCPR (1966). International Covenant on Civil and Political Rights. (1966). Adopted by the General Assembly of the United Nations, Part 1, Article 27 \& 19, 19 December.

Multilateral American Convention on Human Rights (ACHR). "Pact of San Jose, Costa Rica" article 13, signed at San Jose, Costa Rica on 22 November 1969. Available at: https://treaties.un.org/doc/publication/unts/volume\%201144/volume-1144-i-17955english.pdf

Nigeria Public Order Act (1990). Laws of the Federation of Nigeria, Chapter 382.

U.K. Public Order Act (1986). Section 5 (1) (b) as amended 1994.

Universal Declaration of Human Rights (1948). Adopted 10 December 1948. 